\title{
Study on the effects of near-future ocean acidification on marine yeasts: a microcosm approach
}

\author{
Evamaria Krause • Antje Wichels · René Erler • \\ Gunnar Gerdts
}

Received: 6 December 2012/Revised: 5 February 2013/Accepted: 8 February 2013/Published online: 22 February 2013 (c) Springer-Verlag Berlin Heidelberg and AWI 2013

\begin{abstract}
Marine yeasts play an important role in biodegradation and nutrient cycling and are often associated with marine flora and fauna. They show maximum growth at $\mathrm{pH}$ levels lower than present-day seawater $\mathrm{pH}$. Thus, contrary to many other marine organisms, they may actually profit from ocean acidification. Hence, we conducted a microcosm study, incubating natural seawater from the North Sea at present-day $\mathrm{pH}(8.10)$ and two near-future $\mathrm{pH}$ levels (7.81 and 7.67). Yeasts were isolated from the initial seawater sample and after 2 and 4 weeks of incubation. Isolates were classified by matrix-assisted laser desorption/ ionization time-of-flight mass spectrometry (MALDI-TOF MS) and representative isolates were identified by partial sequencing of the large subunit rRNA gene. From the initial seawater sample, we predominantly isolated a yeast-like filamentous fungus related to Aureobasidium pullulans, Cryptococcus sp., Candida sake, and various cold-adapted yeasts. After incubation, we found more different yeast species at near-future $\mathrm{pH}$ levels than at present-day $\mathrm{pH}$. Yeasts reacting to low $\mathrm{pH}$ were related to Leucosporidium scottii, Rhodotorula mucilaginosa, Cryptococcus sp., and Debaryomyces hansenii. Our results suggest that these yeasts will benefit from seawater $\mathrm{pH}$ reductions and give a first indication that the importance of yeasts will increase in a more acidic ocean.
\end{abstract}

Communicated by H.-D. Franke.

E. Krause $(\varangle) \cdot$ A. Wichels · R. Erler · G. Gerdts Alfred Wegener Institute for Polar and Marine Research, Biologische Anstalt Helgoland, Kurpromenade 201, 27498 Helgoland, Germany

e-mail: evamaria.krause@awi.de
Keywords Yeast diversity - Marine fungi $\cdot \mathrm{pH}$ reduction . MALDI-TOF MS · 26S rDNA sequencing

\section{Introduction}

Marine environments are inhabited by a variety of yeast species, which are ecologically important due to their role in biodegradation and their associations with marine plants and animals. Yeasts are distinguished from other fungi by their unicellular growth and belong to the phyla Ascomycota or Basidiomycota, respectively (Kutty and Philip 2008). In seawater, their abundances vary from below ten to up to thousands of culturable cells per liter, with highest numbers reported from near-shore and nutrient-rich areas (Fell 2001). Yeasts play an important role in the breakdown of plant and refractory material and the cycling of nutrients (Meyers and Ahearn 1974; Kutty and Philip 2008) and are frequently found on decaying algae (van Uden and Castelo Branco 1963; Seshadri and Sieburth 1971; Patel 1975). Additionally, yeasts occur associated with marine animals, for example, fish, shrimps, mussels, corals, and seabirds (van Uden and Castelo Branco 1963; Kawakita and van Uden 1965; Ravindran et al. 2001; Burgaud et al. 2010; Yang et al. 2011). Notably, pathogenic yeast species can also cause infections in animal hosts such as marine mammals and copepods (Seki and Fulton 1969; Higgins 2000). For marine fungi in general, the above-mentioned points have been reviewed by, for example, Hyde et al. (1998), Jones (2011), and Richards et al. (2012).

The optimum growth conditions for yeasts and filamentous fungi are at lower $\mathrm{pH}$ levels than those encountered in the seas (Davis 2009; Orij et al. 2011). In pure culture studies, marine yeasts exhibited maximum total growth, highest growth rate, and shortest lag phase at acid 
pH levels, that is, below pH 7 (Norkrans 1966; Hoppe 1972). This preference for low $\mathrm{pH}$ levels leads to the question whether marine fungi will benefit from ocean acidification. Rising $\mathrm{CO}_{2}$ emissions and the resulting uptake of $\mathrm{CO}_{2}$ by the oceans have already caused a reduction in surface seawater $\mathrm{pH}$ of 0.1 units and a further reduction of up to 0.7 units is anticipated with the depletion of all fossil fuel reserves during the next three centuries (Caldeira and Wickett 2003). So far, microbial processes identified to be affected by ocean acidification are nitrogen fixation and cyanobacterial photosynthesis (Liu et al. 2010). A single study reported that fungal sequences increased by more than seven times in coral-associated microbial communities at reduced $\mathrm{pH}$, which was attributed to an increased susceptibility of corals to fungal colonization at reduced pH (Vega Thurber et al. 2009). Yet, almost nothing is known concerning the direct acidification effects on marine occurring yeasts and filamentous fungi. In this study, we focus on marine yeasts, for which previous records are available at our study site (see below).

The investigation of yeasts in diverse aquatic environments has greatly advanced in recent years with the availability of molecular taxonomic methods (Kurtzman 2006). Yeast community composition was reported for, for example, estuarine, coastal, open-ocean, deep-sea, and various extreme habitats (Gadanho et al. 2003, 2006; Gadanho and Sampaio 2004, 2005; Chen et al. 2009; Burgaud et al. 2010; Coelho et al. 2010). For yeast identification, most of these studies sequenced the 600-650-bp D1/D2 region of the large subunit (LSU) rRNA gene, for which ample sequence information is available (Kurtzman and Robnett 1998; Fell et al. 2000). To limit time-consuming and costly sequencing efforts to a small number of representative isolates, most studies employed pre-screening or classification methods. Besides phenotypic classifications, exclusively PCR-based approaches have been applied up to now, such as micro/minisatellite-primed PCR (MSP-PCR) (Gadanho and Sampaio 2002; Gadanho et al. 2003) and restriction fragment length polymorphism (RFLP) analysis (Chen et al. 2009).

An alternative approach to identify and classify yeast species is matrix-assisted laser desorption/ionization timeof-flight mass spectrometry (MALDI-TOF MS). This rapid and cost-effective method allows a comparison of species based on proteomic mass spectra. Mass spectra of unknown yeasts can be measured and aligned with reference spectra filed in a database, ideally leading to species-level identifications. Furthermore, reference spectra created from measurements of one isolate can be compared with those of other isolates to analyze phylogenetic relationships and thus classify unknown organisms. This mass spectrometric technique has been extensively applied to the study of clinically important yeasts, yielding high rates of correct species-level identifications (e.g., Marklein et al. 2009;
Stevenson et al. 2010; van Veen et al. 2010; Dhiman et al. 2011). Yet, to our knowledge, it has not been applied to yeasts in the context of ecological studies. Still the approach is highly promising, as previously demonstrated for environmental bacterial strains (Dieckmann et al. 2005; Oberbeckmann et al. 2011; Emami et al. 2012).

Our study site Helgoland Roads is located near the island Helgoland approximately $50 \mathrm{~km}$ off the German Coast in the North Sea. At this site, yeast abundances (viable cell counts) have been recorded from 1964 to 1966 and from 1980 to 1992 (Meyers et al. 1967; Gerdts et al. 2004) and additional information on yeast identities based on phenotypic identifications is available for certain periods (Meyers et al. 1967; Ahearn and Crow 1980). For our study, a water sample was taken in mid-April 2011 and was incubated in laboratory microcosms at different $\mathrm{pH}$ levels (pH in situ [8.10], 7.81 and 7.67). Yeasts were isolated from the initial seawater sample and after 2 and 4 weeks of incubation. The main objective of this study was thus to investigate whether moderate $\mathrm{pH}$ reductions, as anticipated in the course of ocean acidification, alter yeast community composition. At the same time, we present the first investigation of the yeast community at Helgoland Roads based on molecular taxonomic methods and evaluate the performance of MALDI-TOF MS in identifying and classifying environmental yeast isolates.

\section{Materials and methods}

\section{Experimental setup}

We sampled water at Helgoland Roads $\left(54^{\circ} 11.3^{\prime} \mathrm{N}\right.$, $\left.7^{\circ} 54.0^{\prime} \mathrm{E}\right)$ on April 14, 2011. The study site and microbiological sampling procedures have been described elsewhere (Wiltshire et al. 2010; Teeling et al. 2012). Water temperature was $6.8{ }^{\circ} \mathrm{C}$. The experimental design consisted of three $\mathrm{pH}$ levels, which were the current seawater in situ $\mathrm{pH}(8.10)$ and two near-future $\mathrm{pH}$ levels, $\mathrm{pH} 7.81$ and $\mathrm{pH}$ 7.67. The mean surface $\mathrm{pH}$ in the southern North Sea may reach these values by the year 2100 , assuming atmospheric $\mathrm{CO}_{2}$ of 700 or $1,000 \mathrm{ppm}$, respectively (Blackford and Gilbert 2007). We acidified water samples with $2 \mathrm{M} \mathrm{HCl}$. For each $\mathrm{pH}$ level, we set up ten replicate 1.6-1 glass jars (acid-washed, autoclaved) with an airtight rubber seal. Jars were incubated at $7{ }^{\circ} \mathrm{C}$ in the dark and were mixed daily by inversion. Samples from five replicate jars of each treatment were analyzed after 2 and after 4 weeks, respectively.

Determination of $\mathrm{pH}$ and total alkalinity (TA)

We used a ProLab $3000 \mathrm{pH}$ meter with an IoLine $\mathrm{pH}$ combination electrode with temperature sensor (type 
IL-pHT-A170MF-DIN-N). All pH measurements were taken at $7.0{ }^{\circ} \mathrm{C}$. The electrode was calibrated with standard buffer solutions from freshly opened glass ampoules $(\mathrm{pH}$ 4.01, 6.87, 9.18) (all materials: SI Analytics, Mainz, Germany), that is, we measured $\mathrm{pH}$ on the National Bureau of Standards (NBS) scale. Samples for total alkalinity were filtered through $0.45-\mu \mathrm{m}$-pore-size nitrocellulose filters (Sartorius, Göttingen, Germany) and were stored at $5{ }^{\circ} \mathrm{C}$ in 100-ml bottles closed airtight with screws with Tefloninlet. Samples were analyzed within a week. Total alkalinity was estimated from open-cell duplicate potentiometric titration and calculation with modified Gran plots (Bradshaw et al. 1981), using a TitroLine alpha plus titrator with an IoLine $\mathrm{pH}$ combination electrode with temperature sensor (type IL-pHT-A120MF-DIN-N). The electrode was calibrated with technical buffer solutions from freshly opened glass ampoules ( $\mathrm{pH} 4.0,7.0$ ) (all materials: SI Analytics, Mainz, Germany). Measurements were corrected using Certified Reference Material (CRM, Batch No. 104, Scripps Institution of Oceanography, USA). Calculations of carbon dioxide partial pressure were made with the program CO2calc (Robbins et al. 2010), using the dissociation constants of carbonic acid of Mehrbach et al. (1973), refit by Dickson and Millero (1987), and dissociation constants for $\mathrm{H}_{2} \mathrm{SO}_{4}$ from Dickson (1990).

\section{Yeast isolation and sampling of yeast biomass}

To cultivate yeasts, samples from the initial seawater sample $(10,100,500$, and 1,000 $\mathrm{ml})$ and from the experiment $(10$ and $100 \mathrm{ml})$ were filtered through sterile nitrocellulose filters $(0.45-\mu \mathrm{m}$ pore size, $47 \mathrm{~mm}$ diameter, gray with grid, Sartorius, Göttingen, Germany) applying low pressure (100 mbar). Filters were placed onto Wickerham's YM agar $(0.3 \%$ yeast extract, $0.3 \%$ malt extract, $0.5 \%$ peptone, $1.0 \%$ dextrose, and $2.0 \%$ agar, $\mathrm{pH} 6.2$ ), prepared with sterile filtered seawater from the sampling site and supplemented with $250 \mathrm{mg} \mathrm{l}^{-1}$ chloramphenicol (Sigma, Saint Louis, MO, USA) to inhibit bacterial growth. Furthermore, samples of $500 \mu$ were directly spread onto the same medium using glass beads. Triplicate samples of each volume were incubated at $7^{\circ} \mathrm{C}$ in the dark. After 13 days, all yeast-like colony-forming units were counted and colonies were picked if accessible, that is, not overgrown by filamentous fungi. Isolates were obtained by at least two successive differential streaks on Wickerham's YM agar without chloramphenicol.

For sampling of yeast biomass for DNA extraction and MALDI-TOF MS, single colonies were streaked out on Wickerham's YM agar without chloramphenicol and were incubated at $18^{\circ} \mathrm{C}$ for 6 days. For MALDI-TOF MS, biomass was resuspended in $300 \mu \mathrm{l}$ sterile deionized water and $900 \mu \mathrm{l}$ pure ethanol was added. Samples were mixed by inversion and stored at $-20{ }^{\circ} \mathrm{C}$ until further analysis. For DNA extraction, biomass was resuspended in $300 \mu \mathrm{l}$ STE buffer $(6.7 \%$ sucrose, $50 \mathrm{mM}$ Tris- $\mathrm{HCl}, 1 \mathrm{mM}$ EDTA, pH 8) and stored at $-20{ }^{\circ} \mathrm{C}$ until further analysis.

\section{MALDI-TOF MS}

Cells were extracted using a standard formic acid/acetonitrile method (Mellmann et al. 2008). Extracts (1.2 $\mu \mathrm{l})$ were spotted onto a sample target in duplicate, left to airdry, and were overlaid with $1.2 \mu \mathrm{l}$ of matrix, containing alpha-cyano-4-hydroxycinnamic acid (HCCA) as a saturated solution in $50 \%$ acetonitrile and $2.5 \%$ trifluoracetic acid. For measurements, we used a microflex ${ }^{\mathrm{TM}}$ benchtop instrument (Bruker Daltonics) in the positive linear mode (2,000-20,000 Da). Six spectra were recorded per isolate. To create one spectrum, 240 laser shots were generated at fixed optimal laser energy of $150 \mu \mathrm{J}$ and $3 \mathrm{~ns}$ of pulse width. Spectra were integrated into one reference spectrum for each isolate, which was subsequently compared to reference spectra in the MALDI BIOTYPER database (V3.2.1.0). Additionally, reference spectra of all isolates were compared among each other (MALDI BIOTYPER 3.0 software) and score values were assigned, describing the degree of similarity between different spectra. Values above 2.0 are considered species-level identifications, and values between 1.7 and 2.0 are considered genus-level identifications (Wieser et al. 2012). Consequently, isolates displaying score values above 2.0 among each other were assigned to a MALDI-TOF MS class. Furthermore, a reference spectrum dendrogram was created (MALDI BIOTYPER 3.0 software). In this dendrogram, the relationship between organisms is reflected by an arbitrary distance level, with distances normalized to a maximum value of 1,000. At least one representative isolate of each MALDI-TOF MS class was selected for sequencing. If applicable, we sequenced at least one isolate obtained from the initial seawater sample and one isolate obtained from the experiment, representing the $\mathrm{pH}$ level with the highest number of isolates in this class.

\section{DNA extraction and partial large subunit (LSU) rRNA} gene sequencing

DNA extraction of isolates was performed as previously described (Sapp et al. 2007) omitting the lysozyme step and using an increased incubation temperature of $65^{\circ} \mathrm{C}$ instead of $50{ }^{\circ} \mathrm{C}$ for the cell lysis step (Gadanho et al. 2003). Briefly, cells were lysed by the addition of sodium dodecyl sulfate $(1 \%)$ and DNA extraction was performed using phenol/chloroform. DNA was precipitated with isopropanol, dissolved in sterile water, and stored at $-20{ }^{\circ} \mathrm{C}$. DNA concentration and purity were determined by 
photometry using an Infinite 200 PRO NanoQuant (Tecan, Männedorf, Switzerland).

A ca. 950-bp fragment of the LSU rRNA gene was amplified using forward primer NL1 (5'-GCA TAT CAA TAA GCG GAG GAA AAG-3') (White et al. 1990) and reverse primer LR6 (5'-CGC CAG TTC TGC TTA CC-3') (Fell 2001). PCRs were performed in duplicate in volumes of $50 \mu \mathrm{l}$ containing $50 \mathrm{ng}$ of template DNA, $5 \mu \mathrm{l} \mathrm{Taq}$ Buffer $(10 \times), 1.4 \mu \mathrm{l}$ of each primer $(20 \mu \mathrm{M}), 1.5 \mu \mathrm{l}$ dNTPs (2.5 mM each), and $2.5 \mathrm{U}$ of Taq DNA polymerase (5 Prime, Hamburg, Germany). Amplifications were carried out according to the following protocol: initial denaturation at $94{ }^{\circ} \mathrm{C}$ for $2 \mathrm{~min}$, followed by 30 cycles of denaturation at $94{ }^{\circ} \mathrm{C}$ for $1 \mathrm{~min}$, annealing at $54{ }^{\circ} \mathrm{C}$ for $1 \mathrm{~min}$, and extension at $68{ }^{\circ} \mathrm{C}$ for $1 \mathrm{~min}$, with a final extension step at $68{ }^{\circ} \mathrm{C}$ for $2 \mathrm{~min}$. The duplicate reactions were combined and purified with the QIAquick PCR purification kit (Qiagen, Valencia, CA, USA). Sequencing was performed in both directions using primers NL1 and LR6 with an ABI PRISM 3700 DNA Analyzer (Applied Biosystems, Foster City, CA). The resulting sequences were aligned using ALIGNIR2. $0^{\circledR}$ (LI-COR). In order to determine the closest relative of environmental isolates, sequences were compared with sequences in the GenBank database. The sequences obtained in this study are available from GenBank under the accession numbers JX679415-JX679461 (LSU rRNA).

Phylogenetic analysis

The sequences were phylogenetically analyzed using the ARB $^{\circledR}$ software package (Ludwig et al. 2004). After the addition of the partial LSU gene sequences to the ARB LSU reference database (LSUref_1900, release August 2011), the sequence alignment was carried out with the integrated Fast Aligner. Additionally, the alignment was refined by the comparison of the closest relatives in NCBI retrieved by BLAST. Sequences with more than 1,200 nucleotides were used to calculate the phylogenetic tree. Partial sequences were added using the ARB "parsimony interactive" tool. The phylogenetic relationship of LSU rRNA sequences was deduced by the neighbor-joining method with the correction algorithm of Felsenstein (1993). Matrices were calculated via neighbor-joining based on the phylogenetic distances of the isolates using the "similarity" correction.

\section{Results}

Carbonate chemistry manipulations

The $\mathrm{pH}_{\mathrm{NBS}}$ of the initial seawater sample was 8.10 , which was consequently taken as the in situ or present-day treatment. The corresponding calculated $\mathrm{pCO}_{2}$ was $477 \mu \mathrm{atm}$. The $\mathrm{pH}$ of the incubations remained very constant during the 4 weeks of the experiment, the means of each treatment not deviating more than 0.03 units from the initially adjusted values (Table 1 ). The resulting calculated $p \mathrm{CO}_{2}$ values of the intermediate acidification treatment $\left(\mathrm{pH}_{\mathrm{NBS}}\right.$ 7.81) ranged from 919 to $973 \mu \mathrm{atm}$ and the $p \mathrm{CO}_{2}$ of the high acidification treatment $\left(\mathrm{pH}_{\mathrm{NBS}} 7.67\right)$ from 1,195 to $1,238 \mu \mathrm{atm}$. For the in situ treatment $\left(\mathrm{pH}_{\mathrm{NBS}} 8.10\right)$, we calculated $p \mathrm{CO}_{2}$ values from 459 to $493 \mu$ atm (Table 1).

Yeast isolation

The initial seawater sample yielded $48( \pm 1 \mathrm{SD})$ colonyforming units per liter $\left(\mathrm{cfu}^{-1}\right.$ ). For samples taken during the experiment, a robust estimation of $\mathrm{cfu}^{-1}$ was not possible, due to low colony numbers and the overgrowth by filamentous fungi. The growth of filamentous fungi also frequently hindered the isolation of yeasts. Yet, in total, we were able to pick 89 colonies with yeast appearance, 51 of the initial seawater sample and 38 during the experiment. Of the 38 colonies obtained during the experiment, 21 were isolated after 2 weeks and 17 after 4 weeks of incubation. Concerning the $\mathrm{pH}$ levels, four colonies were picked at $\mathrm{pH}$ in situ, 12 at $\mathrm{pH} 7.81$, and 22 at $\mathrm{pH} 7.67$.

Yeast identification and classification by MALDI-TOF MS and partial LSU rRNA gene sequence analysis

All 89 isolates (both from the initial seawater sample and from the experiment) were analyzed by MADLI-TOF MS. Seven isolates could be directly identified by comparing

Table $1 \mathrm{pH}_{\mathrm{NBS}}$, total alkalinity, and calculated $p \mathrm{CO}_{2}$ at the start of the experiment and after 2 or 4 weeks of incubation

\begin{tabular}{|c|c|c|c|}
\hline Treatment & $\mathrm{pH}_{\mathrm{NBS}}$ & $\begin{array}{l}\text { Total alkalinity } \\
\left(\mu \mathrm{mol} \mathrm{kg}{ }^{-1}\right)\end{array}$ & $\begin{array}{l}p \mathrm{CO}_{2} \\
(\mu \mathrm{atm})\end{array}$ \\
\hline \multicolumn{4}{|l|}{ pH 8.10} \\
\hline Start & 8.10 & 2,362 & 477 \\
\hline Week 2 & $8.12 \pm 0.00$ & $2,366 \pm 5$ & $459 \pm 5$ \\
\hline $\begin{array}{l}\text { Week } 4 \\
\text { pH } 7.81\end{array}$ & $8.09 \pm 0.02$ & $2,354 \pm 21$ & $493 \pm 21$ \\
\hline Start & 7.81 & 2,257 & 931 \\
\hline Week 2 & $7.81 \pm 0.01$ & $2,235 \pm 11$ & $919 \pm 35$ \\
\hline $\begin{array}{l}\text { Week } 4 \\
\text { pH } 7.67\end{array}$ & $7.79 \pm 0.01$ & $2,242 \pm 12$ & $973 \pm 26$ \\
\hline Start & 7.67 & 2,206 & 1,238 \\
\hline Week 2 & $7.70 \pm 0.01$ & $2,193 \pm 2$ & $1,195 \pm 18$ \\
\hline Week 4 & $7.69 \pm 0.01$ & $2,203 \pm 9$ & $1,236 \pm 43$ \\
\hline
\end{tabular}


their mass spectra to reference strains in the MALDI BIOTYPER database: Three isolates (EK61, EK62, EK82) displayed score values above 2.2 with Debaryomyces hansenii DSM 70590 and the remaining four isolates (EK66, EK67, EK76, EK78) were most similar to Rhodotorula mucilaginosa DSM 70403, with score values ranging from 1.9 to 2.2. Furthermore, the latter isolates had score values between 1.7 and 2.0 to $R$. mucilaginosa DSM 18184 and R. mucilaginosa DSM 70404. All other hits to strains in the reference database were $\leq 1.5$, that is, below probable genus-level identifications.

As the majority of isolates could not be identified with the reference strains available in the MALDI BIOTYPER database, mass spectra were compared among isolates and isolates displaying score values above 2.0 among each other were assigned to a MALDI-TOF MS class. This yielded 18 different MALDI-TOF MS classes (Fig. 1), the five largest of them collectively containing 65 isolates. Eight classes consisted of only one isolate.

To resolve the identity of each MALDI-TOF MS class, partial sequences of the LSU rRNA gene were obtained for one or more representative isolates and were compared with reference sequences in the GenBank database (Table 2). Overall, sequencing consistently revealed the same closest relative for isolates within a MALDI-TOF MS class (Table 2). Consequently, we assigned one closest relative, including sequence similarity percentage, to all isolates within a class (Fig. 1). The phylogenetic placement of representative isolates is shown in Fig. 2 for species in the phylum Ascomycota and in Fig. 3 for species in the phylum Basidiomycota.

Concerning the consensus of both methods, sequencing confirmed the MALDI BIOTYPER identification of isolates of class 7 as R. mucilaginosa and of isolates of class 2 as $D$. hansenii. Furthermore, partial LSU rRNA gene sequencing revealed different closest relatives for distinct MALDI-TOF MS classes. In one case, however, the same closest relative and percentage similarity was found for two classes: for both class 16 and class 17, $100 \%$ sequence similarity was found to Guehomyces pullulans AFTOL-ID 718. The close relationship between the two classes was also seen in the reference spectrum dendrogram (Fig. 1). As MALDI-TOF MS score values among the two isolates in class 16 and the only isolate in class 17 were between 1.5 and 1.7, however, both classes were considered as distinct for further analyses.

In total, five out of the 18 MALDI-TOF MS classes were assigned to the Ascomycota ( 31 isolates) and 13 to the Basidiomycota (58 isolates). For three out of the five ascomycete MALDI-TOF MS classes, closest relatives were filamentous fungi of the subphylum Pezizomycotina: class 3 (13 isolates) showed $100 \%$ sequence similarity to the fungal strain Discosphaerina fagi, class 4 (one isolate)
$95 \%$ sequence similarity to the fungal plant pathogen Ramularia pratensis var. pratensis, and class 13 (one isolate) $98 \%$ sequence similarity to the aquatic hyphomycete Tetracladium setigerum. In contrast, all basidiomycete MALDI-TOF MS classes had yeast species as closest relatives.

Regarding species identifications, $100 \%$ sequence similarity to described species was found for nine of the MALDI-TOF MS classes, containing 48 isolates. For two of the classes (classes 4 and 5), each containing only one isolate, sequence similarity to the closest relative was below $97 \%$, hinting at the isolation of new species.

Yeasts in the initial seawater sample

In the initial seawater sample, we found 14 MALDI-TOF MS classes (Table 3), with similar amounts of Ascomycota (22 isolates) and Basidiomycota (29 isolates) (Fig. 1). Considering only MALDI-TOF MS classes representing yeasts however (classes 3, 4, and 13 had filamentous fungi as closest relatives), only 8 ascomycete isolates were obtained, constituting less than $16 \%$ of the yeasts isolated.

The majority of isolates were identified as the filamentous fungus $D$. fagi and as different members of the yeasts Cryptococcus sp. and Candida sake. Rare species were Leucosporidium scottii, Cystofilobasidium infirmominiatum, G. pullulans, Kondoa malvinella, and isolates related to the filamentous fungi $R$. pratensis var. pratensis and T. setigerum (Fig. 1).

Yeasts after incubation at present-day

$\mathrm{pH}$ and near-future $\mathrm{pH}$ levels

Taken together all $\mathrm{pH}$ levels, after incubation, we found eight MALDI-TOF MS classes (Table 3) with higher amounts of Basidiomycota (29 isolates) than Ascomycota (9 isolates) (Fig. 1). Notably, no non-yeast isolates were obtained after incubation.

After incubation at in situ $\mathrm{pH}$, we found three MALDITOF MS classes (Table 3). Two of these, related to C. sake (class 1) and L. scottii (class 18), had also been obtained from the initial seawater sample. Additionally, one new class (class 16), identified as G. pullulans, was found. Yet, a closely related class (class 17), also identified as G. pullulans, was obtained from the initial seawater sample as well (Table 3).

After incubation at near-future $\mathrm{pH}$ levels, we found eight MALDI-TOF MS classes (Table 3). All three classes found after incubation at $\mathrm{pH}$ in situ were found after incubation at the near-future $\mathrm{pH}$ levels as well. Two of the additional classes (classes 11 and 12) were related to Cryptococcus sp. and had been previously detected in the initial seawater sample (Table 3). The remaining three 


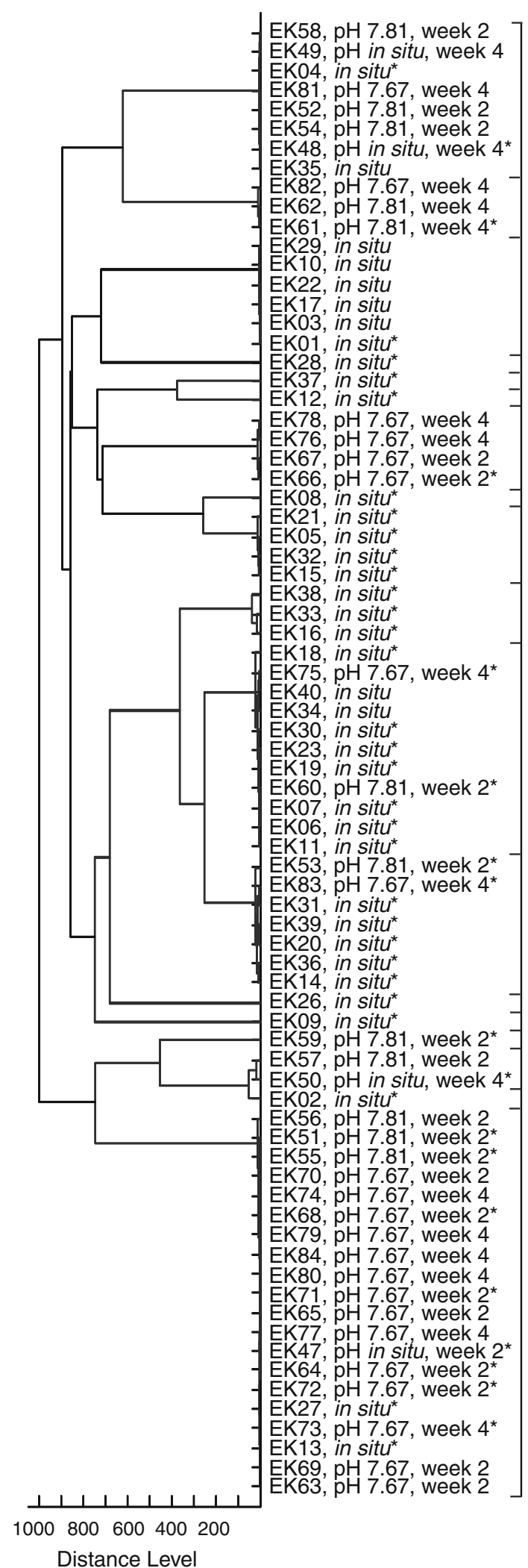

Fig. 1 Reference spectrum dendrogram of isolates, based on MALDITOF mass spectra. Isolates with score values above 2.0 among each other were grouped into classes. Isolates from the original seawater sample are designated as in situ; for isolates obtained after incubation, the $\mathrm{pH}$ level and the time of sampling are indicated. For each MALDI-TOF MS class, the
1 - Candida sake L4 (99) ${ }^{\mathrm{a}}$

2 - Debaryomyces hansenii DAOM 216364 (100)

\section{3 - Discosphaerina fagi $(100)^{a}$}

4 - Ramularia pratensis var. pratensis CPC 11294 (95)

5 - Cystofilobasidium infirmominiatum AFTOL-ID 1888 (99)

6 - Cystofilobasidium infirmominiatum AFTOL-ID 1888 (100)

7 - Rhodotorula mucilaginosa S9 (100)

8 - Cryptococcus sp. CRUB 1154 (100)

9 - Cryptococcus sp. CRUB 1154 (98-99)

10 - Cryptococcus sp. CBS 681.93 AFTOL-ID 719 (100)

11 - Cryptococcus sp. CBS 681.93 AFTOL-ID 719 (99)

12 - Cryptococcus sp. CBS 681.93 AFTOL-ID 719 (98)

13 - Tetracladium setigerum CCM F-10186 (98)

14 - Kondoa malvinella AFTOL-ID 859 (99)

15 - Rhodotorula mucilaginosa S9 (96)

16 - Guehomyces pullulans AFTOL-ID 1958 (100)

17 - Guehomyces pullulans AFTOL-ID 1958 (100)

\section{8 - Leucosporidium scottii AFTOL-ID 718 (100)}

closest relative and similarity (\%) of representative isolates, as determined by partial LSU rRNA gene sequence analysis, are given. Isolates selected for sequencing are marked with an asterisk. ${ }^{a}$ Note that for MALDI-TOF MS class 1 and 3, additional isolates (not displayed) were obtained from the initial seawater sample: 6 isolates of class 1 and 7 isolates of class 3 
Table 2 Taxonomic classification of representative isolates of MALDI-TOF MS classes, based on partial LSU rRNA gene sequence analysis

\begin{tabular}{|c|c|c|c|c|c|c|}
\hline Isolate & $\begin{array}{l}\text { MALDI-TOF } \\
\text { MS class }\end{array}$ & bp & Closest relative (BLAST) & $\begin{array}{l}\text { Accession } \\
\text { number }\end{array}$ & $\begin{array}{l}\text { Similarity } \\
(\%)\end{array}$ & $\begin{array}{l}\text { Fungal } \\
\text { group }\end{array}$ \\
\hline EK04 & 1 & 935 & Candida sake L4 & EF017662 & 99 & A \\
\hline EK48 & 1 & 927 & Candida sake L4 & EF017662 & 99 & A \\
\hline EK61 & 2 & 937 & Debaryomyces hansenii DAOM 216364 & JN938932 & 100 & A \\
\hline EK01 & 3 & 897 & Discosphaerina fagi & AY016359 & 100 & A \\
\hline EK28 & 4 & 931 & Ramularia pratensis var. pratensis CPC 11294 & EU019284 & 95 & A \\
\hline EK37 & 5 & 963 & Cystofilobasidium infirmominiatum AFTOL-ID 1888 & DQ645523 & 99 & $\mathrm{~B}$ \\
\hline EK12 & 6 & 963 & Cystofilobasidium infirmominiatum AFTOL-ID 1888 & DQ645523 & 100 & $\mathrm{~B}$ \\
\hline EK66 & 7 & 941 & Rhodotorula mucilaginosa S9 & AB217506 & 100 & B \\
\hline EK08 & 8 & 969 & Cryptococcus sp. CRUB 1154 & EF595760 & 100 & B \\
\hline EK21 & 9 & 970 & Cryptococcus sp. CRUB 1154 & EF595760 & 98 & B \\
\hline EK05 & 9 & 970 & Cryptococcus sp. CRUB 1154 & EF595760 & 98 & $\mathrm{~B}$ \\
\hline EK32 & 9 & 964 & Cryptococcus sp. CRUB 1154 & EF595760 & 98 & $\mathrm{~B}$ \\
\hline EK15 & 9 & 958 & Cryptococcus sp. CRUB 1154 & EF595760 & 99 & B \\
\hline EK38 & 10 & 945 & Cryptococcus sp. CBS 681.93 AFTOL-ID 719 & AY646103 & 100 & B \\
\hline EK33 & 10 & 960 & Cryptococcus sp. CBS 681.93 AFTOL-ID 719 & AY646103 & 100 & B \\
\hline EK16 & 10 & 750 & Cryptococcus sp. CBS 681.93 AFTOL-ID 719 & AY646103 & 100 & $\mathrm{~B}$ \\
\hline EK18 & 11 & 960 & Cryptococcus sp. CBS 681.93 AFTOL-ID 719 & AY646103 & 99 & $\mathrm{~B}$ \\
\hline EK75 & 11 & 755 & Cryptococcus sp. CBS 681.93 AFTOL-ID 719 & AY646103 & 99 & B \\
\hline EK30 & 11 & 961 & Cryptococcus sp. CBS 681.93 AFTOL-ID 719 & AY646103 & 99 & $\mathrm{~B}$ \\
\hline EK23 & 11 & 960 & Cryptococcus sp. CBS 681.93 AFTOL-ID 719 & AY646103 & 99 & B \\
\hline EK19 & 11 & 960 & Cryptococcus sp. CBS 681.93 AFTOL-ID 719 & AY646103 & 99 & $\mathrm{~B}$ \\
\hline EK60 & 11 & 946 & Cryptococcus sp. CBS 681.93 AFTOL-ID 719 & AY646103 & 99 & B \\
\hline EK07 & 11 & 960 & Cryptococcus sp. CBS 681.93 AFTOL-ID 719 & AY646103 & 99 & B \\
\hline EK06 & 11 & 960 & Cryptococcus sp. CBS 681.93 AFTOL-ID 719 & AY646103 & 99 & B \\
\hline EK11 & 11 & 960 & Cryptococcus sp. CBS 681.93 AFTOL-ID 719 & AY646103 & 99 & B \\
\hline EK53 & 12 & 871 & Cryptococcus sp. CBS 681.93 AFTOL-ID 719 & AY646103 & 98 & $\mathrm{~B}$ \\
\hline EK83 & 12 & 960 & Cryptococcus sp. CBS 681.93 AFTOL-ID 719 & AY646103 & 98 & B \\
\hline EK31 & 12 & 961 & Cryptococcus sp. CBS 681.93 AFTOL-ID 719 & AY646103 & 98 & $\mathrm{~B}$ \\
\hline EK39 & 12 & 960 & Cryptococcus sp. CBS 681.93 AFTOL-ID 719 & AY646103 & 98 & $\mathrm{~B}$ \\
\hline EK20 & 12 & 960 & Cryptococcus sp. CBS 681.93 AFTOL-ID 719 & AY646103 & 98 & B \\
\hline EK36 & 12 & 960 & Cryptococcus sp. CBS 681.93 AFTOL-ID 719 & AY646103 & 98 & $\mathrm{~B}$ \\
\hline EK14 & 12 & 960 & Cryptococcus sp. CBS 681.93 AFTOL-ID 719 & AY646103 & 98 & B \\
\hline EK26 & 13 & 937 & Tetracladium setigerum CCM F-10186 & EU883427 & 98 & A \\
\hline EK09 & 14 & 951 & Kondoa malvinella AFTOL-ID 859 & AY745720 & 99 & B \\
\hline EK59 & 15 & 924 & Rhodotorula mucilaginosa S9 & AB217506 & 96 & $\mathrm{~B}$ \\
\hline EK50 & 16 & 966 & Guehomyces pullulans AFTOL-ID 1958 & EF551318 & 100 & B \\
\hline EK02 & 17 & 966 & Guehomyces pullulans AFTOL-ID 1958 & EF551318 & 100 & B \\
\hline EK51 & 18 & 960 & Leucosporidium scottii AFTOL-ID 718 & AY646098 & 100 & $\mathrm{~B}$ \\
\hline EK55 & 18 & 920 & Leucosporidium scottii AFTOL-ID 718 & AY646098 & 100 & B \\
\hline EK68 & 18 & 953 & Leucosporidium scottii AFTOL-ID 718 & AY646098 & 100 & $\mathrm{~B}$ \\
\hline EK71 & 18 & 953 & Leucosporidium scottii AFTOL-ID 718 & AY646098 & 100 & $\mathrm{~B}$ \\
\hline EK47 & 18 & 959 & Leucosporidium scottii AFTOL-ID 718 & AY646098 & 100 & B \\
\hline EK64 & 18 & 953 & Leucosporidium scottii AFTOL-ID 718 & AY646098 & 100 & B \\
\hline EK72 & 18 & 910 & Leucosporidium scottii AFTOL-ID 718 & AY646098 & 100 & B \\
\hline EK27 & 18 & 780 & Leucosporidium scottii AFTOL-ID 718 & AY646098 & 100 & B \\
\hline EK73 & 18 & 953 & Leucosporidium scottii AFTOL-ID 718 & AY646098 & 100 & B \\
\hline EK13 & 18 & 953 & Leucosporidium scottii AFTOL-ID 718 & AY646098 & 100 & $\mathrm{~B}$ \\
\hline
\end{tabular}

$b p$ base pair, A Ascomycota, $B$ Basidiomycota 


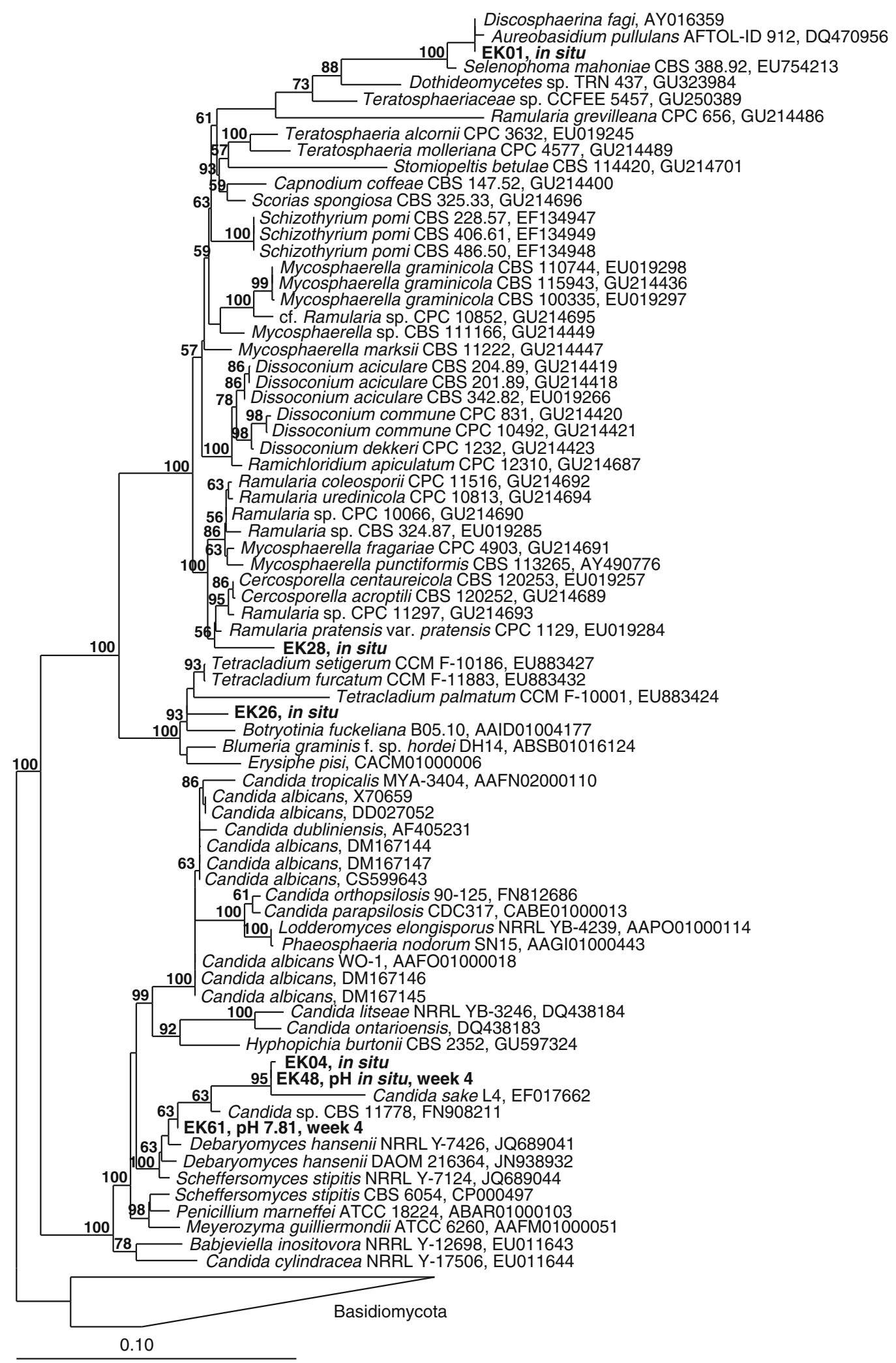

Fig. 2 Phylogenetic tree of members of the phylum Ascomycota, based on partial LSU rRNA gene sequences. Isolates obtained in this study (EK) are highlighted in bold; isolates from the initial seawater sample are designated as in situ; for isolates obtained after incubation, the $\mathrm{pH}$ level and the time of sampling are indicated. GenBank accession numbers are given. Bootstrap values $>50 \%$ are displayed. Scale bar represents 10 nucleotide substitutions per 100 nucleotides. Sequences of isolates obtained in this study are available from GenBank under the accession numbers JX679415-JX679461 
Fig. 3 Phylogenetic tree of members of the phylum Basidiomycota, based on partial LSU rRNA gene sequences. Isolates obtained in this study (EK) are highlighted in bold; isolates from the original seawater sample are designated as in situ; for isolates obtained after incubation, the $\mathrm{pH}$ level, and the time of sampling are indicated. GenBank accession numbers are given. Bootstrap values $>50 \%$ are displayed. Scale bar represents 10 nucleotide substitutions per 100 nucleotides. Sequences of isolates obtained in this study are available from GenBank under the accession numbers JX679415-JX679461

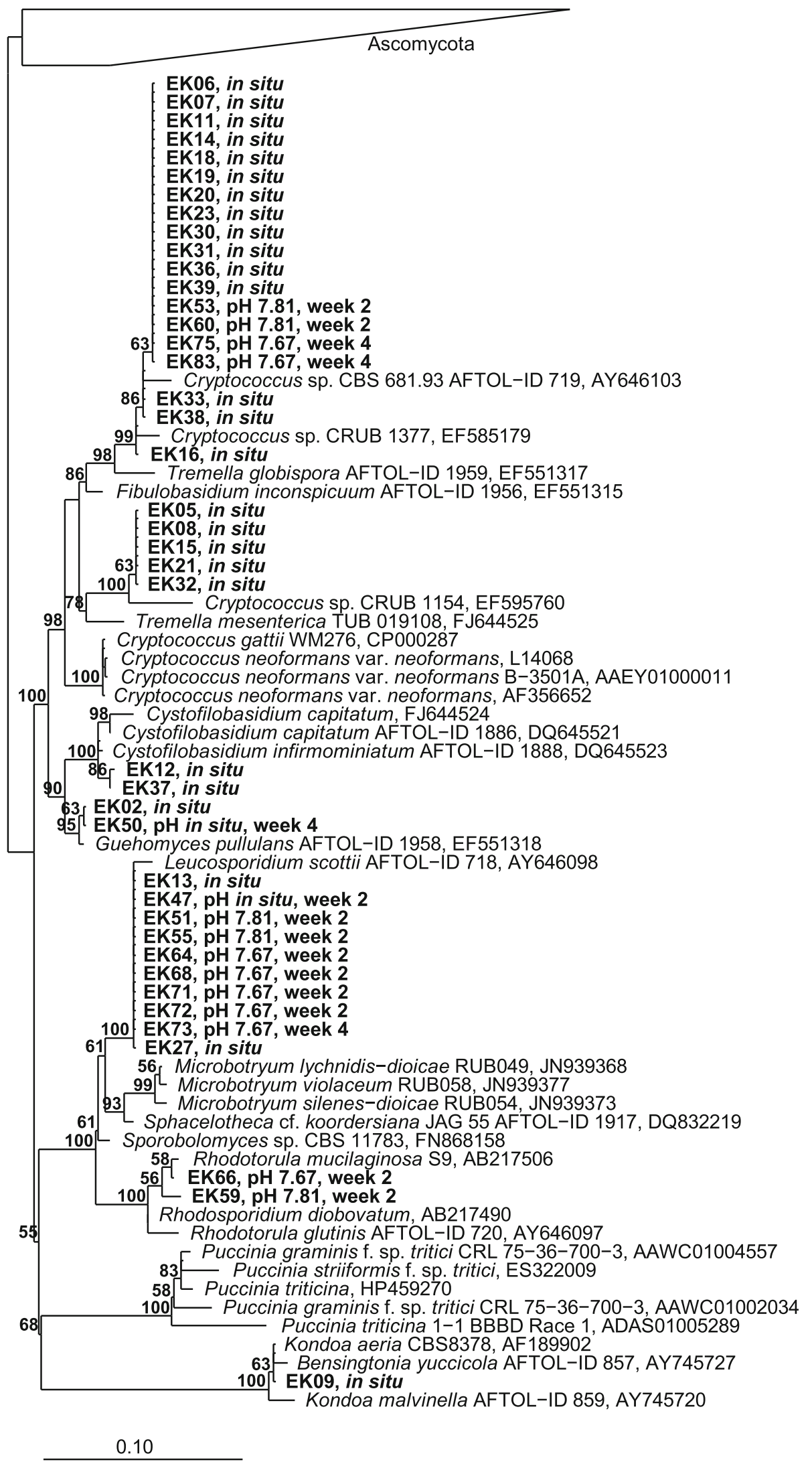


Table 3 Isolates obtained from the initial seawater sample (in situ) and after 2 and 4 weeks of incubation at different $\mathrm{pH}$ levels, based on MALDI-TOF MS classification

\begin{tabular}{|c|c|c|c|c|c|c|c|}
\hline \multirow[t]{2}{*}{ MALDI-TOF MS class ${ }^{\mathrm{a}}$} & \multirow[t]{2}{*}{ in situ } & \multicolumn{2}{|c|}{$\mathrm{pH}$ in situ } & \multicolumn{2}{|l|}{$\mathrm{pH} 7.81$} & \multicolumn{2}{|l|}{$\mathrm{pH} 7.67$} \\
\hline & & Week 2 & Week 4 & Week 2 & Week 4 & Week 2 & Week 4 \\
\hline 1. Candida sake L4 (99) & + & - & + & + & - & - & + \\
\hline 2. Debaryomyces hansenii DAOM 2163648 (100) & - & - & - & - & + & - & + \\
\hline 3. Discosphaerina fagi $(100)$ & + & - & - & - & - & - & - \\
\hline 4. Ramularia pratensis var. pratensis CPC 11294 (95) & + & - & - & - & - & - & - \\
\hline 5. Cystofilobasidium infirmominiatum AFTOL-ID 1888 (99) & + & - & - & - & - & - & - \\
\hline 6. Cystofilobasidium infirmominiatum AFTOL-ID 1888 (100) & + & - & - & - & - & - & - \\
\hline 7. Rhodotorula mucilaginosa S9 (100) & - & - & - & - & - & + & + \\
\hline 8. Cryptococcus sp. CRUB 1154 (100) & + & - & - & - & - & - & - \\
\hline 9. Cryptococcus sp. CRUB 1154 (98-99) & + & - & - & - & - & - & - \\
\hline 10. Cryptococcus sp. CBS 681.93 AFTOL-ID 719 (100) & + & - & - & - & - & - & - \\
\hline 11. Cryptococcus sp. CBS 681.93 AFTOL-ID 719 (99) & + & - & - & + & - & - & + \\
\hline 12. Cryptococcus sp. CBS 681.93 AFTOL-ID 719 (98) & + & - & - & + & - & - & + \\
\hline 13. Tetracladium setigerum CCM F-10186 (98) & + & - & - & - & - & - & - \\
\hline 14. Kondoa malvinella AFTOL-ID 859 (99) & + & - & - & - & - & - & - \\
\hline 15. Rhodotorula mucilaginosa S9 (96) & - & - & - & + & - & - & - \\
\hline 16. Guehomyces pullulans AFTOL-ID 1958 (100) & - & - & + & + & - & - & - \\
\hline 17. Guehomyces pullulans AFTOL-ID 1958 (100) & + & - & - & - & - & - & - \\
\hline 18. Leucosporidium scottii AFTOL-ID 718 (100) & + & + & - & + & - & + & + \\
\hline
\end{tabular}

+ , detected; -, not detected

${ }^{a}$ Given is the closest relative and similarity (\%) of representative isolates of each MALDI-TOF MS class, as determined by partial LSU rRNA gene sequence analysis

classes were found only after incubation at near-future $\mathrm{pH}$ levels and were identified as $R$. mucilaginosa (class 7), $D$. hansenii (class 2), and as related to $R$. mucilaginosa (class 15). The predominant MALDI-TOF MS class found after incubation was class 18 , identified as $L$. scottii. Remarkably, isolates of this class were obtained considerably more often after incubation at near-future $\mathrm{pH}$ levels, especially from pH 7.67 (Fig. 1).

\section{Discussion}

As yeasts prefer low $\mathrm{pH}$, their importance in marine ecosystems may increase with ocean acidification. Using a microcosm approach, we present the first investigation of the effects of moderate $\mathrm{pH}$ reductions on marine yeasts. The possible implications are discussed along with a general consideration of the yeast community at Helgoland Roads and the strategy of identifying and classifying environmental yeast isolates by MALDI-TOF MS.

\section{Carbonate system perturbations}

The $\mathrm{pH}$ values of the microcosms remained very stable during incubation (Table 1). The present-day $\mathrm{pH}$ we measured matched the value reported by Blackford and Gilbert (2007) for the southern North Sea (8.10 vs. $8.06 \pm 0.06 \mathrm{SD}$ ), thus $\mathrm{pH}$ gradations realized in our study closely mimicked near-future $\mathrm{pH}$ levels. However, considering the use of $\mathrm{HCl}$, it has to be taken into account that there are differences in carbonate system changes depending on whether $\mathrm{pH}$ is altered by $\mathrm{HCl}$ or $\mathrm{CO}_{2}$ additions. Although for $\mathrm{CO}_{2}$ not considerably exceeding 700 ppm, all carbonate system parameters change in similar magnitude with both perturbation methods (Schulz et al. 2009), higher acid perturbations lead to lower bicarbonate concentrations than $\mathrm{CO}_{2}$ additions (Schulz et al. 2009; Hurd et al. 2009). Yet, biological responses are not expected to differ substantially as all carbonate system species $\left(\left[\mathrm{CO}_{2}\right],\left[\mathrm{HCO}_{3}{ }^{-}\right],\left[\mathrm{CO}_{3}{ }^{2-}\right],\left[\mathrm{H}^{+}\right]\right)$will change in the same direction with both methods (Gattuso and Lavigne 2009; Schulz et al. 2009).

\section{Yeast identification and classification by MALDI-TOF MS}

Of the 89 environmental isolates obtained in this study, only seven could be directly identified with reference spectra available in the MALDI BIOTYPER database. They were identified as $R$. mucilaginosa or D. hansenii, 
respectively, with score values between 1.9 and 2.2. Sequencing of a ca. 950-bp region of the LSU rDNA confirmed the MALDI-TOF MS identification. Thus, MALDI-TOF MS yielded correct species-level identifications, but the percentage of isolates that could be directly identified was very small, due to the lack of environmental strains in the MALDI BIOTYPER database.

Our results indicate, however, that MALDI-TOF MS can also be used as a rapid tool to classify environmental yeast isolates and thus limit sequencing efforts. Classification proved very reliable: within a MALDI-TOF MS class, partial sequencing of the LSU rRNA gene of representative isolates consistently revealed the same closest relative (Table 2). Likewise, different classes were found to represent different closest relatives and percentage similarities. Yet, one exception occurred, as G. pullulans was found as the closest relative with $100 \%$ sequence similarity for two classes. This may hint at differences at the subspecies level, as isolates in one group originated from the initial seawater sample and in the other group from the experiment. The resolution of sequencing the 950-bp region of the LSU rDNA may not be sufficient to resolve these differences. The problem of multiple groups representing one species is encountered with PCR-based pre-screening methods as well. In a study employing MSP-PCR fingerprints, four different patterns were found among 22 isolates eventually identified as the species D. hansenii var. hansenii (Gadanho et al. 2003). This was not seen as a methodological limitation, however; instead, it was hypothesized to indicate different populations within a species (Gadanho et al. 2003).

In summary, the classification success achieved by MALDI-TOF MS was comparable to that achieved with PCR-based pre-screening methods of environmental yeast isolates (Gadanho and Sampaio 2002; Gadanho et al. 2003; Chen et al. 2009). Yet, direct identification of environmental yeast isolates by MALDI-TOF MS is still limited. As identification successes obtained for clinical yeast isolates are very promising (Marklein et al. 2009; Stevenson et al. 2010; van Veen et al. 2010; Dhiman et al. 2011), an expansion of the database toward environmental isolates is desirable. With these data becoming available, it will be possible to fully exploit the capacity of this rapid and costeffective method for environmental studies.

\section{Yeast community at Helgoland Roads}

At the sampling time in mid-April 2011, we observed 48 yeast colony-forming units per liter $\left(\mathrm{cfu}^{-1}\right)$. This is in the lower range of previous records: at Helgoland Roads, strong fluctuations from less than 10 to up to $600 \mathrm{cfu} 1^{-1}$ were reported, with highest abundances in the summer months (July-September) (Meyers et al. 1967; Crow et al. 1977; Ahearn and Crow 1980; Gerdts et al. 2004).
The most frequently isolated species belonged to typical marine yeast genera and a yeast-like filamentous fungus. Isolates were predominantly identified as related to $D$. fagi, Cryptococcus sp., and C. sake (Fig. 1). Discosphaerina (formerly Columnosphaeria) fagi has been suggested as a possible teleomorph, that is, sexual stage, of the black yeast-like fungus Aureobasidium pullulans (Zalar et al. 2008), which occurs widespread in the marine environment (Meyers et al. 1967). The genera Cryptococcus and Candida are known to contain true marine yeasts (Kutty and Philip 2008) and the species C. sake is present in various aquatic environments including lakes, lagoons, and Antarctic seawater (Boguslawska-Was and Dabrowski 2001; Brandão et al. 2011; Buzzini et al. 2012). Furthermore, members of this species are pathogens of freshwater prawn, fish, and marine invertebrates (Hatai and Egusa 1975; de Araujo et al. 1995; Brilhante et al. 2011).

Among the rare species, the high incidence of species known from cold environments can be pointed out, namely L. scottii, C. infirmominiatum, G. pullulans, and Kondoa malvinella (Fig. 1). These species occur in Arctic or Antarctic seawater, algae, and glacial environments (Fonseca et al. 2000; Vaz et al. 2011; Buzzini et al. 2012). However, most of them have also been reported from soil (Maksimova and Chernov 2004; Lim et al. 2010) or associated with animals (Bruce and Morris 1973; Kobatake et al. 1992; Zacchi and Vaughan-Martini 2002), including deep-sea corals and mussels (Burgaud et al. 2010; Galkiewicz et al. 2012). Additionally, we found two filamentous fungi of terrestrial or freshwater origin. These were related to the $R$. pratensis var. pratensis, a necrotrophic plant pathogen described on Rumex crispus (Crous et al. 2007), and the aquatic hyphomycete $T$. setigerum. Aquatic hyphomycetes are important decomposers of leaf litter in running waters and are dispersed as spores on substrates such as wood or in the digestive tract of aquatic detrivores (Anderson and Shearer 2011). These species may have been introduced by coastal water influx, which is known to recur at the study site (Wiltshire et al. 2010).

Comparing the species composition observed to earlier reports from the North Sea and the study site (1964-1966 and 1980-1992) reveals both similarities and differences. Cryptococcus and Candida species, A. pullulans and C. infirmominiatum (under the previous designation Rhodosporidium infirmio-miniata) have previously been reported from the North Sea (Meyers et al. 1967; Meyers and Ahearn 1974; Ahearn and Crow 1980; Crow et al. 1977). However, we found D. hansenii and R. mucilaginosa (formerly $R$. rubra) only after incubation (Table 3), although they were the most abundant species in North Sea water samples in both 1964-1966 and 1976 (Meyers et al. 1967; Ahearn and Crow 1980). This could be related to seasonality, as especially $D$. hansenii was reported to occur 
with algal blooms and is closely related to high nutrient situations (Meyers et al. 1967; Ahearn and Crow 1980). In contrast, our study was carried out in mid-April, at the beginning of the spring bloom (chlorophyll a on April 14, 2011: $4.5 \mu \mathrm{g} \mathrm{l}^{-1}$, maximum on April 26, 2011: $15.4 \mu \mathrm{g}$ $1^{-1}$; data obtained from the Helgoland Roads time series (Wiltshire et al. 2008)). Furthermore, although year-round sampling campaigns were previously conducted, no reports about cold-adapted yeast species exist. The differences may in part be explained as we used a different isolation medium and a lower incubation temperature ( 7 versus $18^{\circ} \mathrm{C}$ ). Additionally, our identifications are based on sequencing, whereas previous observations were based on morphology and biochemical capabilities.

In summary, the initial yeast community, taken as starting point for the experiment, displayed the characteristics of a typical marine sample with coastal influences. It comprised mainly true marine species but also some species of terrestrial or freshwater origin. In addition, various cold-adapted yeasts were present, possibly due to the relatively high latitude of the study site and the time of sampling in mid-April. The differences to previous records suggest a more detailed reinvestigation of the North Sea yeast community using molecular methods.

Yeasts after incubation: present-day versus near-future pH levels

At in situ $\mathrm{pH}$, we only found yeasts related to $C$. sake, L. scottii, and G. pullulans, which were all found in the initial seawater sample as well (Table 3). At near-future $\mathrm{pH}$ levels, we additionally found yeasts related to Cryptococcus sp., R. mucilaginosa, and D. hansenii (Table 3). Thus, after incubation at near-future $\mathrm{pH}$ levels, we recovered a higher number of species than after incubation at presentday $\mathrm{pH}$. Furthermore, we obtained yeasts not detected in the initial seawater sample only after incubation at nearfuture $\mathrm{pH}$ levels. This indicates that these species profited from reduced $\mathrm{pH}$. In terms of total yeast abundances, however, no calculations can be presented. Still it is remarkable that more isolates were obtained from nearfuture $\mathrm{pH}$ incubations. Especially for L. scottii, the number of isolates was inversely related to $\mathrm{pH}$ (Fig. 1), suggesting that a moderate reduction in $\mathrm{pH}$ may lead to higher yeast abundances.

Our results yield only first insights though, as we were not able to quantitatively isolate all yeasts due to the overgrowth by filamentous fungi. Furthermore, the maximum sampling volume was $100 \mathrm{ml}$ for the incubations, compared to $1,000 \mathrm{ml}$ for the initial seawater sample, reducing the possibility of detection of rare species. Using a nutrient-rich medium and a direct detection method (DGGE), Gadanho and Sampaio (2004) observed a higher number of yeast species, especially ascomycetes, after incubation. Thus, the low number of species we found after incubation may also be explained by nutrient limitation. For bacteria, the phenomenon of community shifts in laboratory incubations has long been known as the "bottle effect" (Ferguson et al. 1984). Yet, to our knowledge, no detailed investigations of the response of marine yeast communities to experimental confinement exist and estimates on the percentage of culturable marine yeasts are lacking (Fell 2001). Recently, a DGGE analysis of mycoplankton of Hawaiian coastal waters revealed many new fungal phylotypes but not a single match with fungi previously cultured from this environment (Gao et al. 2010). Therefore, future studies on ocean acidification effects on marine yeasts should include direct detection methods.

Despite these limitations, our findings indicate that L. scottii, R. mucilaginosa, and related species, Cryptococcus sp. and $D$. hansenii, grow better at near-future seawater $\mathrm{pH}$ levels. In general, alkaline $\mathrm{pH}$ is considered to be a stress factor that yeasts have to cope with in the marine environment. The intracellular $\mathrm{pH}$ of yeasts was reported to be around 7 when growing on glucose in laboratory studies and to remain stable between extracellular $\mathrm{pH}$ values from 3.0 to 7.5 (Orij et al. 2009). At lower external pH values, protons can be efficiently exported out of the cytoplasm, either to the exterior of the cell or into the vacuole, involving different ATPases (Carmelo et al. 1997; Diakov and Kane 2010; Orij et al. 2011). In contrast, alkaline external $\mathrm{pH}$ values exacerbate the establishment of a functional plasma membrane proton gradient and consequently the uptake of nutrients (Orij et al. 2011). Thus, a moderate reduction in seawater $\mathrm{pH}$ partially relieves the $\mathrm{pH}$ stress yeasts encounter in the marine environment. This may hold true for fungi in general, as osmotrophic feeding driven by the plasma membrane proton gradient is a characteristic feature of this group (Davis 2009; Richards et al. 2012). The extent to which different species will benefit may depend on their specific $\mathrm{pH}$ regulation mechanisms, as was recently proposed for marine bacteria (Teira et al. 2012).

Taking into account that more fungi are found in corals exposed to $\mathrm{pH}$ stress (Vega Thurber et al. 2009), our results indicate that with ocean acidification, both direct and indirect $\mathrm{pH}$ effects may favor fungi. Although our results on yeasts abundances remain preliminary, this gives rise to some concern, as particularly the genera we isolated at near-future $\mathrm{pH}$ levels also contain pathogenic species. Members of Cryptococcus sp. are known to infect marine mammals (Higgins 2000) and also humans (Khawcharoenporn et al. 2007). Likewise, R. mucilaginosa and $D$. hansenii are considered emerging yeast pathogens (Hazen 1995). Notably, the importance of yeasts in surveillance programs at bathing beaches has already been pointed out (Vogel et al. 2007; Shah et al. 2011). 
Concerning microbial food webs, it is furthermore interesting to note that a moderate acidification does not seem to influence bacterial abundances (Grossart et al. 2006; Allgaier et al. 2008; Krause et al. 2012; Newbold et al. 2012). A possible consequence would be a relative increase in the importance of yeasts in biogeochemical cycles.

In conclusion, this study yields valuable first insights concerning the effects of ocean acidification on marine yeasts. We demonstrate that especially $L$. scottii, $R$. mucilaginosa, Cryptococcus sp., and D. hansenii benefit from moderate $\mathrm{pH}$ reductions. Furthermore, a moderate reduction in $\mathrm{pH}$ seems to be generally beneficial to the yeast community, suggesting a higher importance of yeasts in a more acidic ocean. The implications for biogeochemical cycles and pathogenic interactions deserve a thorough investigation in future ocean acidification studies.

Acknowledgments Financial support was provided by Federal Ministry of Education and Research (BMBF Project Biological Impacts of Ocean ACIDification, BIOACID, FKZ 03F0608B). We thank Maarten Boersma for fruitful discussions and helpful comments to improve an earlier version of this manuscript. Furthermore, we thank Diana Höhlig and Jonathan Herlet for their valuable contribution to this study and the crew of the RV Aade from the Alfred Wegener Institute of Polar and Marine Research Helgoland for the sampling support.

Conflict of interest The authors declare that they have no conflict of interest.

Ethical standards The experiments described comply with the current German laws.

\section{References}

Ahearn DG, Crow SA (1980) Yeasts from the North Sea and Amoco Cadiz oil. Bot Mar 23:125-127

Allgaier M, Riebesell U, Vogt M, Thyrhaug R, Grossart HP (2008) Coupling of heterotrophic bacteria to phytoplankton bloom development at different $p \mathrm{CO}_{2}$ levels: a mesocosm study. Biogeosciences 5:1007-1022

Anderson JL, Shearer CA (2011) Population genetics of the aquatic fungus Tetracladium marchalianum over space and time. PLoS ONE 6:e15908

Blackford JC, Gilbert FJ (2007) $\mathrm{pH}$ variability and $\mathrm{CO}_{2}$ induced acidification in the North Sea. J Mar Syst 64:229-241

Boguslawska-Was E, Dabrowski W (2001) The seasonal variability of yeasts and yeast-like organisms in water and bottom sediment of the Szczecin Lagoon. Int J Hyg Environ Health 203:451-458

Bradshaw AL, Brewer PG, Shafer DK, Williams RT (1981) Measurements of total carbon dioxide and alkalinity by potentiometric titration in the GEOSECS program. Earth Planet Sci Lett 55:99-115

Brandão LR, Libkind D, Vaz ABM, Espírito Santo LC, Moliné M, de García V, van Broock M, Rosa CA (2011) Yeasts from an oligotrophic lake in Patagonia (Argentina): diversity, distribution and synthesis of photoprotective compounds and extracellular enzymes. FEMS Microbiol Ecol 76:1-13

Brilhante RSN, Paiva MAN, Sampaio CMS, Teixeira CEC, CasteloBranco DSCM, Leite JJG, Moreira CA, Silva LP, Cordeiro RA, Monteiro AJ, Sidrim JJC, Rocha MFG (2011) Yeasts from
Macrobrachium amazonicum: a focus on antifungal susceptibility and virulence factors of Candida spp. FEMS Microbiol Ecol 76:268-277

Bruce J, Morris EO (1973) Psychrophilic yeasts isolated from marine fish. Antonie Van Leeuwenhoek 39:331-339

Burgaud G, Arzur D, Durand L, Cambon-Bonavita MA, Barbier G (2010) Marine culturable yeasts in deep-sea hydrothermal vents: species richness and association with fauna. FEMS Microbiol Ecol 73:121-133

Buzzini P, Branda E, Goretti M, Turchetti B (2012) Psychrophilic yeasts from worldwide glacial habitats: diversity, adaptation strategies and biotechnological potential. FEMS Microbiol Ecol 82:217-241

Caldeira K, Wickett ME (2003) Anthropogenic carbon and ocean pH. Nature 425:365

Carmelo V, Santos H, Sá-Correia I (1997) Effect of extracellular acidification on the activity of plasma membrane ATPase and on the cytosolic and vacuolar $\mathrm{pH}$ of Saccharomyces cerevisiae. Biochim Biophys Acta 1325:63-70

Chen YS, Yanagida F, Chen LY (2009) Isolation of marine yeasts from coastal waters of northeastern Taiwan. Aquat Biol 8:55-60

Coelho MA, Almeida JMF, Martins IM, da Silva AJ, Sampaio JP (2010) The dynamics of the yeast community of the Tagus river estuary: testing the hypothesis of the multiple origins of estuarine yeasts. Antonie Van Leeuwenhoek 98:331-342

Crous PW, Braun U, Groenewald JZ (2007) Mycosphaerella is polyphyletic. Stud Mycol 58:1-32

Crow SA, Bowman PI, Ahearn DG (1977) Isolation of atypical Candida albicans from the North Sea. Appl Environ Microbiol 33:738-739

Davis DA (2009) How human pathogenic fungi sense and adapt to $\mathrm{pH}$ : the link to virulence. Curr Opin Microbiol 12:365-370

de Araujo FV, Soares CAG, Hagler AN, Mendonça-Hagler LC (1995) Ascomycetous yeast communities of marine invertebrates in a Southeast Brazilian mangrove ecosystem. Antonie Van Leeuwenhoek 68:91-99

Dhiman N, Hall L, Wohlfiel SL, Buckwalter SP, Wengenack NL (2011) Performance and cost analysis of Matrix-Assisted Laser Desorption Ionization-Time of Flight Mass Spectrometry for routine identification of yeast. J Clin Microbiol 49(4):1614-1616

Diakov TT, Kane PM (2010) Regulation of vacuolar protontranslocating ATPase activity and assembly by extracellular pH. J Biol Chem 285:23771-23778

Dickson AG (1990) Standard potential of the reaction: $\mathrm{AgCl}(\mathrm{s})+1 /$ $2 \mathrm{H}_{2}(\mathrm{~g})=\mathrm{Ag}(\mathrm{s})+\mathrm{HCl}(\mathrm{aq})$, and the standard acidity constant of the ion $\mathrm{HSO}_{4}{ }^{-}$in synthetic sea water from 273.15 to $318.15 \mathrm{~K}$. J Chem Thermodyn 22:113-127

Dickson AG, Millero FJ (1987) A comparison of the equilibrium constants for the dissociation of carbonic acid in seawater media. Deep Sea Res A 34:1733-1743

Dieckmann R, Graeber I, Kaesler I, Szewzyk U, von Döhren H (2005) Rapid screening and dereplication of bacterial isolates from marine sponges of the Sula Ridge by Intact-Cell-MALDI-TOF mass spectrometry (ICM-MS). Appl Microbiol Biotechnol 67:539-548

Emami K, Askari V, Ullrich M, Mohinudeen K, Anil AC, Khandeparker L, Burgess JG, Mesbahi E (2012) Characterization of bacteria in ballast water using MALDI-TOF mass spectrometry. PLoS ONE 7:e38515

Fell JW (2001) Collection and identification of marine yeasts. In: Paul $\mathrm{J}$ (ed) Methods in microbiology, vol 30. Academic Press, New York, pp 347-356

Fell JW, Boekhout T, Fonseca A, Scorzetti G, Statzell-Tallman A (2000) Biodiversity and systematics of basidiomycetous yeasts as determined by large-subunit rDNA D1/D2 domain sequence analysis. Int J Syst Evol Microbiol 50:1351-1371 
Felsenstein J (1993) PHYLIP (Phylogeny Inference Package). 3.5c ed Ferguson RL, Buckley EN, Palumbo AV (1984) Response of marine bacterioplankton to differential filtration and confinement. Appl Environ Microbiol 47:49-55

Fonseca Á, Sampaio JP, Inácio J, Fell JW (2000) Emendation of the basidiomycetous yeast genus Kondoa and the description of Kondoa aeria sp. nov. Antonie Van Leeuwenhoek 77:293-302

Gadanho M, Sampaio JP (2002) Polyphasic taxonomy of the basidiomycetous yeast genus Rhodotorula: Rh. glutinis sensu stricto and Rh. dairenensis comb. nov. FEMS Yeast Res 2:47-58

Gadanho M, Sampaio JP (2004) Application of temperature gradient gel electrophoresis to the study of yeast diversity in the estuary of the Tagus river, Portugal. FEMS Yeast Res 5:253-261

Gadanho M, Sampaio JP (2005) Occurrence and diversity of yeasts in the Mid-Atlantic ridge hydrothermal fields near the Azores Archipelago. Microb Ecol 50:408-417

Gadanho M, Almeida JMGCF, Sampaio JP (2003) Assessment of yeast diversity in a marine environment in the south of Portugal by microsatellite-primed PCR. Antonie Van Leeuwenhoek 84: 217-227

Gadanho M, Libkind D, Sampaio JP (2006) Yeast diversity in the extreme acidic environments of the Iberian Pyrite Belt. Microb Ecol 52:552-563

Galkiewicz JP, Stellick SH, Gray MA, Kellogg CA (2012) Cultured fungal associates from the deep-sea coral Lophelia pertusa. Deep Sea Res Part I Oceanogr Res Pap 67:12-20

Gao Z, Johnson ZI, Wang G (2010) Molecular characterization of the spatial diversity and novel lineages of mycoplankton in Hawaiian coastal waters. ISME J 4:111-120

Gattuso JP, Lavigne H (2009) Technical note: approaches and software tools to investigate the impact of ocean acidification. Biogeosciences 6:2121-2133

Gerdts G, Wichels A, Döpke H, Klings KW, Gunkel W, Schütt C (2004) 40-year long-term study of microbial parameters near Helgoland (German Bight, North Sea): historical view and future perspectives. Helgol Mar Res 58:230-242

Grossart HP, Allgaier M, Passow U, Riebesell U (2006) Testing the effect of $\mathrm{CO}_{2}$ concentration on the dynamics of marine heterotrophic bacterioplankton. Limnol Oceanogr 51:1-11

Hatai K, Egusa S (1975) Candida sake from gastro-tympanites of amago, Onchorynchus rhodurus. Bull Jpn Soc Sci Fish 41:993

Hazen KC (1995) New and emerging yeast pathogens. Clin Microbiol Rev 8:462-478

Higgins R (2000) Bacteria and fungi of marine mammals: a review. Can Vet J 41:105-116

Hoppe HG (1972) Untersuchungen zur Ökologie der Hefen im Bereich der westlichen Ostsee. Kiel Meeresforsch 28:54-77

Hurd CL, Hepburn CD, Currie KI, Raven JA, Hunter KA (2009) Testing the effects of ocean acidification on algal metabolism: considerations for experimental designs. J Phycol 45:1236-1251

Hyde KD, Jones EBG, Leano E, Pointing SB, Poonyth AD, Vrijmoed LLP (1998) Role of fungi in marine ecosystems. Biodivers Conserv 7:1147-1161

Jones EBG (2011) Are there more marine fungi to be described? Bot Mar 54:343-354

Kawakita S, van Uden N (1965) Occurrence and population densities of yeast species in the digestive tracts of gulls and terns. J Gen Microbiol 39:125-129

Khawcharoenporn T, Apisarnthanarak A, Mundy LM (2007) Nonneoformans cryptococcal infections: a systematic review. Infection 35:51-58

Kobatake M, Kreger van Rij NJW, Plácido MTLC, Van Uden N (1992) Isolation of proteolytic psychrotrophic yeasts from fresh raw seafoods. Lett Appl Microbiol 14:37-42
Krause E, Wichels A, Giménez L, Lunau M, Schilhabel MB, Gerdts $\mathrm{G}$ (2012) Small changes in $\mathrm{pH}$ have direct effects on marine bacterial community composition: a microcosm approach. PLoS ONE 7:e47035

Kurtzman CP (2006) Yeast species recognition from gene sequence analyses and other molecular methods. Mycoscience 47:65-71

Kurtzman CP, Robnett CJ (1998) Identification and phylogeny of ascomycetous yeasts from analysis of nuclear large subunit (26S) ribosomal DNA partial sequences. Antonie Van Leeuwenhoek 73:331-371

Kutty SN, Philip R (2008) Marine yeasts-a review. Yeast 25:465483

Lim YW, Kim BK, Kim C, Jung HS, Kim BS, Lee JH, Chun J (2010) Assessment of soil fungal communities using pyrosequencing. J Microbiol 48:284-289

Liu JW, Weinbauer MG, Maier C, Dai M, Gattuso JP (2010) Effect of ocean acidification on microbial diversity and on microbe-driven biogeochemistry and ecosystem functioning. Aquat Microb Ecol 61:291-305

Ludwig W, Strunk O, Westram R, Richter L, Meier H, Yadhukumar, Buchner A, Lai T, Steppi S, Jobb G, Förster W, Brettske I, Gerber S, Ginhart AW, Gross O, Grumann S, Hermann S, Jost R, König A, Liss T, Lüßmann R, May M, Nonhoff B, Reichel B, Strehlow R, Stamatakis A, Stuckmann N, Vilbig A, Lenke M, Ludwig T, Bode A, Schleifer KH (2004) ARB: a software environment for sequence data. Nucleic Acids Res 32:1363-1371

Maksimova IA, Chernov IY (2004) Community structure of yeast fungi in forest biogeocenoses. Microbiology 73:474-481

Marklein G, Josten M, Klanke U, Müller E, Horré R, Maier T, Wenzel T, Kostrzewa M, Bierbaum G, Hoerauf A, Sahl HG (2009) Matrix-assisted laser desorption ionization-time of flight mass spectrometry for fast and reliable identification of clinical yeast isolates. J Clin Microbiol 47:2912-2917

Mehrbach C, Culberson CH, Hawley JE, Pytkowicz RM (1973) Measurement of the apparent dissociation constants of carbonic acid in seawater at atmospheric pressure. Limnol Oceanogr 18:897-907

Mellmann A, Cloud J, Maier T, Keckevoet U, Ramminger I, Iwen P, Dunn J, Hall G, Wilson D, LaSala P, Kostrzewa M, Harmsen D (2008) Evaluation of matrix-assisted laser desorption ionizationtime-of-flight mass spectrometry in comparison to $16 \mathrm{~S}$ rRNA gene sequencing for species identification of nonfermenting bacteria. J Clin Microbiol 46:1946-1954

Meyers SP, Ahearn DG (1974) Implication of yeasts and yeast-like fungi in marine processes. Veröff Inst Meeresforsch Bremerhav Suppl 5:321-338

Meyers SP, Ahearn DG, Gunkel W, Roth FJJ (1967) Yeasts from the North Sea. Mar Biol 1:118-123

Newbold LK, Oliver AE, Booth T, Tiwari B, Desantis T, Maguire M, Andersen G, van der Gast CJ, Whiteley AS (2012) The response of marine picoplankton to ocean acidification. Environ Microbiol 14:2293-2307

Norkrans B (1966) Studies on marine occurring yeasts: growth related to $\mathrm{pH}, \mathrm{NaCl}$ concentration and temperature. Arch Mikrobiol 54:374-392

Oberbeckmann S, Wichels A, Maier T, Kostrzewa M, Raffelberg S, Gerdts G (2011) A polyphasic approach for the differentiation of environmental Vibrio isolates from temperate waters. FEMS Microbiol Ecol 75:145-162

Orij R, Postmus J, Ter Beek A, Brul S, Smits GJ (2009) In vivo measurement of cytosolic and mitochondrial $\mathrm{pH}$ using a $\mathrm{pH}$ sensitive GFP derivative in Saccharomyces cerevisiae reveals a relation between intracellular $\mathrm{pH}$ and growth. Microbiology $155: 268-278$ 
Orij R, Brul S, Smits GJ (2011) Intracellular pH is a tightly controlled signal in yeast. Biochim Biophys Acta 1810:933-944

Patel KS (1975) The relationship between yeasts and marine algae. Proc Indian Acad Sci 82:25-28

Ravindran J, Raghukumar C, Raghukumar S (2001) Fungi in Porites lutea: association with healthy and diseased corals. Dis Aquat Org 47:219-228

Richards T, Jones M, Leonard G, Bass D (2012) Marine fungi: their ecology and molecular diversity. Ann Rev Mar Sci 4:495-522

Robbins LL, Hansen ME, Kleypas JA, Meylan SC (2010) CO2calca user-friendly seawater carbon calculator for Windows, Max OS $\mathrm{X}$, and iOS (iPhone). U.S. Geological Survey Open-File Report 2010-1280

Sapp M, Wichels A, Wiltshire KH, Gerdts G (2007) Bacterial community dynamics during the winter-spring transition in the North Sea. FEMS Microbiol Ecol 59:622-637

Schulz KG, Barcelos e Ramos JBE, Zeebe RE, Riebesell U (2009) $\mathrm{CO}_{2}$ perturbation experiments: similarities and differences between dissolved inorganic carbon and total alkalinity manipulations. Biogeosciences 6:2145-2153

Seki H, Fulton J (1969) Infection of marine copepods by Metschnikowia sp. Mycopathologia 38:61-70

Seshadri R, Sieburth JM (1971) Cultural estimation of yeasts on seaweeds. Appl Microbiol 22:507-512

Shah AH, Abdelzaher AM, Phillips M, Hernandez R, Solo-Gabriele HM, Kish J, Scorzetti G, Fell JW, Diaz MR, Scott TM, Lukasik J, Harwood VJ, McQuaig S, Sinigalliano CD, Gidley ML, Wanless D, Ager A, Lui J, Stewart JR, Plano LRW, Fleming LE (2011) Indicator microbes correlate with pathogenic bacteria, yeasts and helminthes in sand at a subtropical recreational beach site. J Appl Microbiol 110:1571-1583

Stevenson LG, Drake SK, Shea YR, Zelazny AM, Murray PR (2010) Evaluation of matrix-assisted laser desorption ionization-time of flight mass spectrometry for identification of clinically important yeast species. J Clin Microbiol 48:3482-3486

Teeling H, Fuchs BM, Becher D, Klockow C, Gardebrecht A, Bennke CM, Kassabgy M, Huang S, Mann AJ, Waldmann J, Weber M, Klindworth A, Otto A, Lange J, Bernhardt J, Reinsch C, Hecker M, Peplies J, Bockelmann FD, Callies U, Gerdts G, Wichels A, Wiltshire KH, Glöckner FO, Schweder T, Amann R (2012) Substrate-controlled succession of marine bacterioplankton populations induced by a phytoplankton bloom. Science 336 : 608-611

Teira E, Fernández A, Álvarez-Salgado XA, García-Martín EE, Serret $\mathrm{P}$, Sobrino C (2012) Response of two marine bacterial isolates to high $\mathrm{CO}_{2}$ concentration. Mar Ecol Prog Ser 453:27-36 van Uden N, Castelo Branco R (1963) Distribution and population densities of yeast species in Pacific water, air, animals, and kelp off southern California. Limnol Oceanogr 8:323-329

van Veen SQ, Claas ECJ, Kuijper EJ (2010) High-throughput identification of bacteria and yeast by matrix-assisted laser desorption ionization-time of flight mass spectrometry in conventional medical microbiology laboratories. J Clin Microbiol 48:900-907

Vaz ABM, Rosa LH, Vieira MLA, de Garcia V, Brandão LR, Teixeira LCRS, Moliné M, Libkind D, van Broock M, Rosa CA (2011) The diversity, extracellular enzymatic activities and photoprotective compounds of yeasts isolated in Antarctica. Braz J Microbiol 42:937-947

Vega Thurber R, Willner-Hall D, Rodriguez-Mueller B, Desnues C, Edwards RA, Angly F, Dinsdale E, Kelly L, Rohwer F (2009) Metagenomic analysis of stressed coral holobionts. Environ Microbiol 11:2148-2163

Vogel C, Rogerson A, Schatz S, Laubach H, Tallman A, Fell J (2007) Prevalence of yeasts in beach sand at three bathing beaches in South Florida. Water Res 41:1915-1920

White TJ, Bruns T, Lee S, Taylor J (1990) Amplification and direct sequencing of fungal ribosomal RNA genes for phylogenetics. In: Innis MA, Gelfand DH, Sninsky JJ, White TJ (eds) PCR protocols: a guide to methods and applications. Academic Press, San Diego, CA, pp 315-324

Wieser A, Schneider L, Jung J, Schubert S (2012) MALDI-TOF MS in microbiological diagnostics-identification of microorganisms and beyond (mini review). Appl Microbiol Biotechnol 93:965-974

Wiltshire KH, Malzahn AM, Wirtz K, Greve W, Janisch S, Mangelsdorf P, Manly BFJ, Boersma M (2008) Resilience of North Sea phytoplankton spring bloom dynamics: an analysis of long-term data at Helgoland Roads. Limnol Oceanogr 53:1294-1302

Wiltshire KH, Kraberg A, Bartsch I, Boersma M, Franke HD, Freund J, Gebühr C, Gerdts G, Stockmann K, Wichels A (2010) Helgoland Roads, North Sea: 45 years of change. Estuar Coast 33:295-310

Yang SP, Wu ZH, Jian JC (2011) Distribution of marine red yeasts in shrimps and the environments of shrimp culture. Curr Microbiol 62:1638-1642

Zacchi L, Vaughan-Martini A (2002) Yeasts associated with insects in agricultural areas of Perugia, Italy. Ann Microbiol 52:237-244

Zalar P, Gostinčar C, de Hoog GS, Uršič V, Sudhadham M, GundeCimerman N (2008) Redefinition of Aureobasidium pullulans and its varieties. Stud Mycol 61:21-38 